\title{
DIE VERBAND TUSSEN PERSOONLIKHEID EN STEMHIPERFUNKSIE BY 'N BEPAALDE GROEP SPREKERS
}

\author{
Lani Grey \\ B Kommunikasiepatologie \\ Anita van der Merwe \\ D Phil (Spraakheelkunde) \\ Departement Kommunikasiepatologie, Universiteit van Pretoria \\ Korresponderende outeur:vdmerwea@postino.up.ac.za
}

\section{Loray Daws \\ MA (Kliniese Sielkunde) \\ Departement Sielkunde, Universiteit van Pretoria}

Sleutelwoorde: stemband nodules, stemhiperfunksie, persoonlikheid, professionele stemgebruik Key words: vocal nodules, voice hyperfunction, personality, professional voice use

\section{SUMMARY}

People who use their voices in their daily profession sometimes tend to suffer vocal abuse and fatigue. Vocal abuse, also known as vocal hyperfunction, can lead to the surgical removal of vocal nodules. In order to ensure more effective service delivery in these cases, researchers and clinicians have to view the causal factors from a broad perspective. Due to the close relationship between personality and voice it is important to investigate personality factors that may have an influence on the development of vocal hyperfunction. The aim of this study was to determine whether similar personality characteristics occur in a group of speakers with vocal fold nodules and to investigate the group's results on the 16PF personality questionnaire. A group of twelve female students who were all potential professional voice users was studied. The group showed elevated levels of extroversion, which implies that they have a tendency to be socially aggressive, talkative and also display an inability to moderate their exuberance during conversation. These qualities can lead to the development of vocal hyperfunction and it appears that the group's extroverted personalities translate to speech behaviour associated with vocal hyperfunction. The implications for the traditional team of clinicians involved in the treatment of voice hyperfunction are discussed.

\section{OPSOMMING}

Persone wat hulle stemme in die uitoefen van hulle beroep gebruik, is soms geneig tot stemmisbruik en stemuitputting. Stemmisbruik, ook genoem stemhiperfunksie, kan aanleiding gee tot stembandnodules wat sjirurgies verwyder moet word. Ten einde meer effektiewe diens te lewer in hierdie gevalle, word navorsers en klinici genoodsaak om die oorsaaklike faktore vanuit 'n wye perspektief te benader. Vanweë die noue verband tussen persoonlikheid en stem is dit belangrik om ondersoek in te stel na persoonlikheidsfaktore wat 'n invloed mag hê op die ontstaan van stemhiperfunksie. Die doel van hierdie studie was om te bepaal of daar ooreenstemmende persoonlikheidseienskappe voorkom by 'n groep sprekers met nodules en om te bepaal hoe die groep manifesteer op elke faktorskaal van die 16PF persoonlikheidsvraelys. 'n Groep van twaalf damestudente wat potensiële professionele stemgebruikers is, is ondersoek. Die groep het verhoogde vlakke van ekstroversie getoon wat onder andere meebring dat hulle sosiaal aggressief en spraaksaam is en dit moeilik vind om hulle uitgelatenheid te kontroleer tydens 'n gesprek. Hierdie persoonlikheidseienskappe kan lei tot stemhiperfunksie en dit blyk dat hierdie persone se ekstroversiewe geaardhede omgeskakel of oorgedra word na spraakgedrag wat lei tot 
stemhiperfunksie. Die implikasies vir die tradisionele span klinici wat betrokke is by die hantering van stemhiperfunksie word bespreek.

\section{RASIONAAL EN PROBLEEMSTELLING}

Stem word voortgebring deur die interaksie van asemhaling (respirasie), stembandbeweging (fonasie) en die resonering van die klankgolwe in die ruimtes bokant die stembande. Professionele stemgebruikers is persone wat afhanklik is van effektiewe stemproduksie om hul beroepsfunksies te kan uitvoer. Voorbeelde van persone wat hul stemme vir die doeleindes van hulle beroep gebruik, is dosente, onderwysers, verpleegkundiges, akteurs, predikante, geneeshere, arbeids-, fisio- en spraak-taalterapeute, advokate en prokureurs. In werklikheid vereis die meeste beroepe die professionele gebruik van die stem. Professionele stemgebruikers neig egter dikwels tot stemmisbruik en stemuitputting, ook genoem stemhiperfunksie. Funksionele stemhiperfunksie is die betrokkenheid van te veel spierkrag en fisiese inspanning in die sisteme van respirasie, fonasie en resonansie (Boone \& McFarlane, 1993). Stemhiperfunksie kan uiteindelik lei tot die ontstaan van stembandnodules, wanneer die stem in so 'n mate herhaaldelik misbruik word dat histologiese veranderinge intree op die stembande (Rubin \& Lehrhoff, 1962; Boone \& McFarlane, 1993). Die ontstaan van stembandnodules en die gevolglike sjirurgie het dikwels uiters negatiewe gevolge vir die persoon se beroepsbeoefening, veral indien die nodules herhaaldelik voorkom.

Stembandnodules is die algemeenste goedaardige gewas van die stembande. Dit word beskryf as bilaterale, witterige uitgroeisels op die glottale rante van die stembande, gelokaliseer by die aansluiting van die anterior derde en posterior twee derdes van elke stemband (Boone \& McFarlane, 1993). Die ontstaan van stembandnodules word toegeskryf aan 'n kombinasie van faktore, hoofsaaklik kroniese, herhaaldelike misbruik van die stem, wat kenmerkend van stemhiperfunksie is. Die behandeling van stemhiperfunksie en gevolglike nodules geskied binne 'n interdissiplinêre spanverband en sluit tans stemkonservering en stemrehabilitasie deur 'n spraaktaalterapeut in, asook sjirurgiese verwydering van die noduleweefsel deur'n oor-, neus- en keelsjirurg indien fibrose reeds plaasgevind het. Die sukses van intervensie word egter deur navorsers bevraagteken, aangesien langtermynuitkomste van behandeling nie altyd bevredigend is nie: " ...it appears that despite efforts of surgeons and voice therapists, the lesions in some adults are resistant to therapy and/or tend to recur" (Roy \& Bless, 2000b:470). Swak langtermynuitkomste in die behandeling van nodules weens stemhiperfunksie noodsaak klinici om 'n meer holistiese perspektief aan te hang ten einde alle oorsaaklike faktore effektief aan te spreek (Lavorato \& McFarlane, 1988; Boone, 1991). Vanuit 'n holistiese perspektief sal daar onder andere deeglik rekening gehou moet word met die noue verband tussen stem en persoonlikheid (Moses, 1954) en met die moontlike rol van persoonlikheid by die ontstaan en instandhouding van stemhiperfunksie. Die psigosomatiese fenomeen beklemtoon die rol van stres en ander persoonlikheidsfaktore in die ontwikkeling en instandhouding van liggaamlike patologie of siekte (Daws, 1999). In hierdie opsig kan sielkundiges moontlik' $n$ waardevolle bydrae lewer in die behandeling van persone met stemhiperfunksie. Die sielkundige kan ook die persoon ondersteun en berading verskaf tydens gedragsmodifikasie, aangesien die persoon baie aanpassings moet maak in spraakgedrag, byvoorbeeld om minder te praat en om ander spraakgewoontes aan te leer. Sielkundiges word nie tradisioneel gereken as 'n integrale deel van die behandelingspan in die hantering van stemhiperfunksie nie, maar indien navorsing kan aantoon dat daar wel 'n verband is tussen stemhiperfunksie en persoonlikheidseienskappe sou dit gerade wees om die benadering tot intervensie te heroorweeg.

Die literatuur getuig egter van kontroversie en onsekerheid rondom die psigiese of psigosomatiese oorsprong van stemhiperfunksie. Hierdie kontroversie bring mee dat stemhiperfunksie met gevolglike nodules in die literatuur deur verskillende outeurs in verskillende kategorieë van stemafwykings geplaas word (Morrison \& Rammage, 1994). Aronson (1990) argumenteer vir die gebruik van die term 'psigogeen' in plaas van 'funksioneel' as klassifikasie van die oorsaak van nodules weens stemhiperfunksie, juis 
omdat dit 'n definitiewe onderliggende psigiese komponent impliseer. Hy definieer psigogene stemafwykings as 'n groep stemafwykings wat bestaan in die afwesigheid van organiese patologie en beskryf dit as ' $n$ manifestasie van een of meer tipes sielkundige disekwilibrium wat inmeng met normale beheer van fonasie (Aronson, 1990). Persone wat presenteer met nodules weens stemhiperfunksie word onder andere beskryf as spraaksaam, gespanne en sosiaal aggressief met interpersoonlike probleme wat spanning, woede en depressie kan genereer (Arnold, 1962; Greene \& Mathieson, 1989; Aronson, 1990).

Roy en Bless (2000a) noem egter dat psigiese faktore nie oorbeklemtoon moet word nie, maar slegs in ag geneem moet word as bydraende of instandhoudende faktore ten opsigte van funksionele stemhiperfunksie. Volgens Roy en Bless (2000a) klassifiseer outeurs funksionele stemhiperfunksie op grond van hul persoonlike oriëntasie, aangesien daar ' $n$ tekort is aan objektiewe navorsing in die literatuur wat die verband tussen persoonlikheid en funksionele stemhiperfunksie ondersoek. Daar is wel aanduidings in die literatuur dat daar moontlik ' $n$ verband kan wees, maar daar is steeds ' $n$ behoefte aan verdere navorsing om huidige hipoteses te bevestig (Yano, Ichimura, Hoshino \& Nozue, 1982; Roy, Bless \& Heisey, 2000a; Roy \& Bless, 2000b). Die motivering vir hierdie studie is dus die behoefte aan navorsing aangaande die verband tussen persoonlikheid en stemhiperfunksie, in 'n poging om die effektiwiteit van dienslewering te verhoog. Die doel van die studie is om te bepaal of daar kenmerkende persoonlikheidseienskappe voorkom by 'n groep sprekers met funksionele stemhiperfunksie en gevolglike nodules en om te bepaal hoe die groep manifesteer op die kontinuum van elke persoonlikheidsfaktor van die 16PF persoonlikheidsvraelys.

\section{METODE}

\section{Navorsingsdoelwit}

Die doel van hierdie studie was om 'n persoonlikheidsprofiel op te stel vir 'n groep sprekers met funksionele stemhiperfunksie en gevolglike nodules deur te bepaal hoe die groep manifesteer op die kontinuum van elke persoonlikheidsfaktor van die 16PF persoonlikheidsvraelys. Die proefgroep se resultate is vergelyk met die vasgestelde norms van die persoonlikheidsvraelys, ten einde te bepaal of die groep enige homogene kenmerke vertoon.

\section{Navorsingsontwerp}

'n Kruissnitstudie is gebruik, met ander woorde 'n verskynsel se huidige status is ondersoek, sonder om veranderlikes te manipuleer oor die verloop van 'n sekere tydperk (Neuman, 1997). Die datainsamelingstegniek was deur middel van 'n gestandaardiseerde persoonlikheidsvraelys wat deur die proefpersone ingevul is. Ouderdoms-en geslagstoepaslike norms van die persoonlikheidsvraelys het gedien as kontrole vir die proefgroep se resultate (Prinsloo, 1991).

\section{Proefpersone}

Twaalf vroulike studente met stemhiperfunksie en gevolglike nodules is geselekteer vir die proefgroep. Al die proefpersone was potensiële professionele stemgebruikers, uit die studierigtings Regte, Kommunikasiepatologie, Musiek en Drama. Die redes vir die uitsluiting van manlike proefpersone was die feit dat die meerderheid van persone met nodules vroulik is (Goldman, Hargrave, Hillman, Holmberg \& Gress 1996) en om die groep meer homogeen te hou. Die diagnose van stemhiperfunksie en gepaardgaande stembandnodules is deur 'n oor-, neus- en keelarts en ervare spraak-taalterapeut gemaak. Dit was nie van belang watter tipe nodules (soos bilateraal of unilateraal), die persoon ontwikkel het nie aangesien enige tipe nodule op stemhiperfunksie dui. Al die proefpersone het ten tye van die studie gestudeer aan 'n tersiêre instansie en hul ouderdomme het gewissel vanaf 18 tot 21 jaar. Al die proefpersone moes van 'n Westerse afkoms wees en Afrikaans of Engels magtig wees, aangesien die toets kultuurgebonde is en slegs in Afrikaans en Engels beskikbaar is. Om die betroubaarheid van die resultate te verhoog, is slegs persone ingesluit by wie nodules in die afgelope twee jaar gediagnoseer is. Die proefpersone mag geen ander kommunikasie-afwykings getoon het nie, aangesien dit 'n invloed op die persoon se persoonlikheidsontwikkelling kan hê. Laastens mag die persoon geen psigoterapie ontvang het in die verlede nie, insluitend vir behandeling van stemhiperfunksie of ' $n$ geskiedenis van emosionele probleme, weens die moontlike invloed 
daarvan op die persoon se persoonlikheidsprofiel (Daws, 2001).

\section{Materiaal: Die 16PF Persoonlikheids- vraelys}

Om die studie se doelwitte te bereik, is die sestien faktor persoonlikheidsvraelys (16PF) geselekteer as toetsmateriaal (Cattell, 1970; Smit, 1991). Hierdie besluit is in konsultasie met ' $n$ ervare kliniese sielkundige geneem (derde outeur). Die 16PF is opgestel in 1961 deur Raymond B. Cattell. Sedertdien het daar'n aantal hersiene weergawes verskyn wat deur die Raad vir Geesteswetenskaplike Navorsing gestandaardiseer is vir Suid-Afrikaanse toestande. Die toetsvorm A van die 1992-weergawe word vir die doeleindes van hierdie studie gebruik (Prinsloo, 1991).

Die 16PF vraelys berus op die analise van verskeie persoonlikheidsfaktore, verteenwoordig deur 187 items op die vraelys met multi-keuse antwoorde. Die eerste sestien faktore, sogenaamde eerste-orde faktore, word op grond van analise van die vraelys bepaal. Cattell (1970) het verder 'n aantal tweede-orde faktore geïdentifiseer, wat verkry word deur statistiese manipulasie van 'n bepaalde kombinasie van eersteorde faktore. Die tweede-orde faktore ondersoek dus die verhoudings tussen 'n individu se onderskeie eerste-orde faktore, byvoorbeeld: 'n persoon se neiging tot kompulsiwiteit (gemeet op tweede-orde faktorskaal III) word afgelei van die persoon se gesamentlike tellings op eerste-orde faktorskale $\mathrm{G}$ (opportunisties teenoor konsensieus) en Q3 (sorgeloos teenoor selfbeheersd). Die tweede-orde faktore kan op dieselfde wyse as eerste-orde faktore voorgestel word, naamlik op 10-puntskale. Die twee pole van elke faktorskaal stel twee uiterste karaktereienskappe van 'n persoonlikheidsfaktor voor (bv. terughoudend teenoor hartlik). 'n Lae telling is dus nie noodwendig negatief en 'n hoër telling positief nie, maar dui slegs op die teenwoordigheid van een van twee teenoorgestelde karaktereienskappe (Cattell, 1970). Die mediaan van al die skale is 5.5, wat die skeidslyn vorm tussen die betrokke twee teenoorgestelde karaktereienskappe. Faktortellings wat afwyk van die mediaan, dus tellings laer of hoër as 5.5, is 'n aanduiding dat 'n persoon meer neig na die spesifieke pool of karaktereienskap op die skaal. Hoe laer of hoër die persoon se telling ten opsigte van die faktorskaal se mediaan is, hoe sterker neig die persoon om die betrokke karaktereienskap te toon. Tabel 1 verskaf ' $n$ opsomming van die 16 eerste-orde faktore en 5 tweede-orde faktore wat deur die faktorskale gemeet word. Dit is belangrik om daarop te let dat persone volgens die skale op 'n kontinuum geëvalueer word. Tabel 1 verskaf slegs die uiterste hipoteses volgens ekstreme faktortellings. Die leser word daarop gewys dat die numering van Cattell (1970) se faktorskale verwarrend kan wees. Cattell (1970) het sommige faktore uit sy oorspronklike lys van faktore om die 16PF te vorm, uitgeskakel en daarom lyk die eerste-orde faktore se volgorde vreemd. Die eerste-orde faktore is ook volgens Arabiese numering genommer en die tweede-orde faktore volgens Romeinse numering. Vanaf die verskillende persoonlikheids-faktorskale word 'n persoonlikheidsprofiel uiteindelik saamgestel en visueel voorgestel, wat 'n persoon se aard en karaktertrekke kan beskryf aan die hand van die verskillende persoonlikheidsfaktore.

\section{Etiese aspekte van die studie}

Elke proefpersoon het ' $n$ inligtingstuk ontvang waarin die doel en prosedures van die studie uiteengesit is. Etiese aspekte wat ook aangespreek is, was die reg van die persoon om anoniem te bly, asook die feit dat individuele terugvoer nie geskied nie, aangesien die studie nie individuele resultate oplewer nie, maar fokus op die groep se gemiddelde resultate. Elke proefpersoon moes ' $n$ brief onderteken as erkenning dat hy kennis geneem het van bogenoemde aspekte. Toestemming is ook verleen deur die studentedekaan van die tersiêre instansie waaraan die studente verbonde is om die resultate van die studie te gebruik vir navorsingsdoeleindes.

\section{Insameling van die data}

Daar is nou saamgewerk met 'n kliniese sielkundige, vanweë die psigometriese aard van die toetsmateriaal. Alle proefpersone is individueel getoets en voorafbepaalde instruksies (soos voorgestel deur Cattell, 1970) is aan die proefpersone uiteengesit. Dit neem ongeveer vyftig minute om die vraelys in te vul. 
Tabel 1: Opsomming van die 16PF persoonlikheidsvraelys se 16 eerste-orde faktore en 5 tweede-orde faktorskale (Cattell, 1970; Smit, 1991)

\begin{tabular}{|c|c|c|}
\hline $\begin{array}{l}\text { 1e orde } \\
\text { Factor- } \\
\text { skaal }\end{array}$ & Lae telling beskrywing & Hoë telling beskrywing \\
\hline A & $\begin{array}{l}\text { Terughoudend: Versigtig in belewing van } \\
\text { emosies, krities, onbetrokke by ander. }\end{array}$ & $\begin{array}{l}\text { Hartlik: goedhartig, na buite-lewend, beleef teenoor } \\
\text { ander, aanpasbaar en gemaklik. }\end{array}$ \\
\hline $\mathrm{B}$ & $\begin{array}{l}\text { Laer gekristalliseerde intelligensie: 'n konkrete } \\
\text { denker, begryp en leer stadiger. }\end{array}$ & $\begin{array}{l}\text { Hoër gekristalliseerde intelligensie: 'n abstrakte } \\
\text { denker, vlug van begrip. }\end{array}$ \\
\hline C & $\begin{array}{l}\text { Beïnvloedbaar. Vol kwellings, het veranderende } \\
\text { houdings en uitkyke, ontwyk } \\
\text { verantwoordelikheid, emosioneel minder stabiel. }\end{array}$ & $\begin{array}{l}\text { Emosionele stabiliteit. Emosioneel volwasse, } \\
\text { realisties, stabiele houdings en gesindhede. }\end{array}$ \\
\hline $\mathrm{E}$ & $\begin{array}{l}\text { Nederig: gehoorsaam, toegeeflik, bedagsaam, } \\
\text { konvensioneel en onderdanig. }\end{array}$ & $\begin{array}{l}\text { Selfgeldend: } \quad \text { selfversekerd, dominant, } \\
\text { mededingend, koppig en eiewys. }\end{array}$ \\
\hline $\mathrm{F}$ & $\begin{array}{l}\text { Sober: stil, introspektief, getrou aan innerlike } \\
\text { waardes, besorgd en peinsend. }\end{array}$ & $\begin{array}{l}\text { Onverskillig: sorgvry, uitgelate entoesiasties, } \\
\text { spraaksaam, ekspressief en op-en-wakker. }\end{array}$ \\
\hline G & $\begin{array}{l}\text { Opportunisties: wispelturig, ongeërg en } \\
\text { onbestendig, verontagsaam reëls. }\end{array}$ & $\begin{array}{l}\text { Konsensieus: verantwoordelik, volhardend, } \\
\text { konsekwent met 'n pligsbesef. }\end{array}$ \\
\hline $\mathrm{H}$ & $\begin{array}{l}\text { Skaam: teruggetrokke, selfbewus, afsydig, } \\
\text { geheimsinnig en toon emosionele versigtigheid. }\end{array}$ & $\begin{array}{l}\text { Waaghalsig: ongebonde, spontaan, sosiaal } \\
\text { avontuurlustig, joviaal en aktief. }\end{array}$ \\
\hline $\mathrm{I}$ & Ontoegeeflik: realisties, prakties, logies, 'hard'. & $\begin{array}{l}\text { Emosionele gevoeligheid: teerhartig, saggeaard en } \\
\text { emosioneel sensitief. }\end{array}$ \\
\hline $\mathrm{L}$ & $\begin{array}{l}\text { Vertrouend: aanvaardend, ontspanne, soms } \\
\text { met 'n gebrek aan ambisie. }\end{array}$ & $\begin{array}{l}\text { Agterdogtig: wantrouig, het ' } n \text { sterk opinie, soms } \\
\text { foutvinderig en sinies, het hoë innerlike spanning. }\end{array}$ \\
\hline $\bar{M}$ & $\begin{array}{l}\text { Prakties: konvensioneel, versigtig en } \\
\text { gestruktureerd, glo aan objektiewe werklikheid. }\end{array}$ & $\begin{array}{l}\text { Verbeeldingryk: onkonvensioneel, verstrooid, neig } \\
\text { om somtyds swak praktiese oordeel te toon. }\end{array}$ \\
\hline $\mathrm{N}$ & $\begin{array}{l}\text { Reguit: ongekunsteld, opreg, sosiaal onbeholpe } \\
\text { en sentimenteel. }\end{array}$ & $\begin{array}{l}\text { Skerpsinnig: goeie selfinsig en insig in ander, } \\
\text { oonwegend en deurdringend. }\end{array}$ \\
\hline $\mathrm{O}$ & $\begin{array}{l}\text { Selfversekerd: vertroue in eie oordeel, vermoë } \\
\text { om bedaard en opgeruimd te wees. }\end{array}$ & $\begin{array}{l}\text { Bekommerd: besorgd, selfverwytend, angstig, } \\
\text { teneergedruk en vreesagtig. }\end{array}$ \\
\hline
\end{tabular}




\begin{tabular}{|c|c|c|}
\hline Q1 & $\begin{array}{l}\text { Konserwatief: respekteer ander se gevestigde } \\
\text { idees, hou nie van verandering nie. }\end{array}$ & $\begin{array}{l}\text { Ondersoekend: krities, analities, liberaal en } \\
\text { vrydenkend. }\end{array}$ \\
\hline Q2 & $\begin{array}{l}\text { Groepsafhanklik: volgelinge en aanhangers, } \\
\text { afhanklik van groepsgoedkeuring. }\end{array}$ & $\begin{array}{lll}\text { Selfgenoegsaam: } & \text { vindingryk, } & \text { vermy } \\
\text { groepsintegrasie. } & & \end{array}$ \\
\hline Q3 & $\begin{array}{l}\text { Sorgeloos: toon minag van sosiale etiket, volg } \\
\text { eie impulse met minder emosionele kontrole. }\end{array}$ & $\begin{array}{l}\text { Selfbeheersd: kompulsief, self-gedissiplineerd, } \\
\text { sosiaal korrek met 'n sterk wilskrag. }\end{array}$ \\
\hline Q4 & $\begin{array}{l}\text { Ontspanne: ervaar min spanning, is nie } \\
\text { gefrustreerd nie, vreedsaam. }\end{array}$ & $\begin{array}{l}\text { Gespanne: het dryfkrag, is aktief, rusteloos, } \\
\text { ongeduldig en prikkelbaar. }\end{array}$ \\
\hline $\begin{array}{l}\text { 2e orde } \\
\text { Faktor - } \\
\text { skaal }\end{array}$ & Lae telling beskrywing & Hoë telling beskrywing \\
\hline$\overline{Q(i)}$ & $\begin{array}{l}\text { Introversie: skaam, teruggetrokke, geïnhibeerd } \\
\text { en selfgenoegsaam in sosiale omgang. }\end{array}$ & $\begin{array}{l}\text { Ekstroversie: hartlik, na buite-lewend, } \\
\text { ongeïnhibeerd en bedrewe in interpersoonlike } \\
\text { verhoudings. }\end{array}$ \\
\hline Q(ii) & $\begin{array}{l}\text { Lae angs: vervulde lewe, in staat om dit wat vir } \\
\text { hom/haar belangrik is, te doen of bereik. } \\
\text { Somtyds egter aanduidend van 'n gebrek aan } \\
\text { gemotiveerdheid. }\end{array}$ & $\begin{array}{l}\text { Hoë angs: toon dikwels aanpassingsproblematiek, } \\
\text { ondervind probleme rondom die hantering van } \\
\text { alledaagse eise. 'n Baie hoë angstelling is } \\
\text { gewoonlik ontwrigtend en lei ook tot fisiese } \\
\text { steuringe. }\end{array}$ \\
\hline Q(iii) & $\begin{array}{l}\text { Gevoelsafhanklikheid: emosioneel sensitief en } \\
\text { geneig om probleme eerder op ' } n \text { affektiewe } \\
\text { manier te hanteer as op ' } n \text { rasionele wyse. }\end{array}$ & $\begin{array}{l}\text { Kortikaliteit: afsydig, gehard en minder geneig tot } \\
\text { fantasieë. Ingestel daarop om probleme op 'n } \\
\text { rasionele wyse te hanteer. }\end{array}$ \\
\hline$Q$ (iv) & $\begin{array}{l}\text { Afhanklikheid: onderdanig en groepsafhanklik } \\
\text { met ' } n \text { behoefte aan ondersteuning van ander } \\
\text { persone. }\end{array}$ & $\begin{array}{l}\text { Onafhanklikheid: aggressief, onafhanklik en } \\
\text { waaghalsig. }\end{array}$ \\
\hline$Q(v)$ & $\begin{array}{l}\text { Impulsiwiteit: Kontroleer nie gedrag deeglik nie } \\
\text { en skroom nie om 'n besluit te neem nie. }\end{array}$ & $\begin{array}{l}\text { Kompulsiviteit: neig om gedrag deeglik te } \\
\text { kontroleer. }\end{array}$ \\
\hline
\end{tabular}




\section{Analise en verwerking van die data}

Die 16PF is ' $\mathrm{C}$ C-vlak psigometriese toets. Die data is deur 'n gekwalifiseerde kliniese sielkundige ontleed. Eerstens is die motiveringsdistorsie telling (MD telling) bereken vir elke individu. Hierdie telling word deur 'n vasgestelde formule verwerk en is ' $n$ aanduiding van 'n proefpersoon se mate van responsingesteldheid, met ander woorde waar 'n proefpersoon poog om 'n gunstige of ongunstige beeld te skep deur sosiaal aanvaarbare response te gee. Al die proefpersone behalwe een, proefpersoon $\mathrm{H}$, se MD tellings was binne normale perke. Laasgenoemde persoon het ' $n$ baie hoë MD telling gehad, wat daarop dui dat sy tydens beantwoording van die vraelys waarskynlik gepoog het om sosiaal aanvaarbare antwoorde te gee. Daws (2001) noem dat sulke persone kan neig om psigosomatiese simptome te manifesteer. Na berekening van die persone se MD-tellings is elke antwoordblad afsonderlik gemerk met verskillende maskers wat elk 'n spesifieke persoonlikheidsfaktor se telling bepaal. Die routellings vir elke persoonlikheidsfaktor is deur die navorser verwerk na 'n stientelling, volgens die norms wat gestandaardiseer is vir Suid-Afrikaanse toestande vir eerstejaar damestudente vir die 16PF persoonlikheidsvraelys (Prinsloo, 1991). Die stientellings is visueel voorgestel op verskillende tienpunt faktorskale vir die onderskeie persoonlikheidsfaktore, soos voorgestel deur Cattell (1970). Daarna is elke persoon se tweede-orde faktore ook bereken deur die voorgeskrewe statistiese manipulasie van 'n spesifieke kombinasie van eersteorde faktore. Die resultate is dus objektief verkry en dieselfde prosedure is op al die proefpersone toegepas. Prosedures vir kruisvalidasie was dus nie nodig in hierdie studie nie.

Die tellings van die onderskeie eerste-orde faktore en tweede-orde faktore van al twaalf proefpersone is verwerk om gemiddelde tellings vir die groep te verkry vir die verskillende faktore. Dit is gedoen deur die onderskeie tellings bymekaar te tel en daarna te deel deur die aantal proefpersone. Die algemene neiging van die groep as geheel is beskryf met betrekking tot spesifieke persoonlikheidsfaktore. Waar daar egter noemenswaardige diskrepansies was tussen die individuele proefpersone se tellings, is dit in ag geneem tydens die analise en interpretasie van die resultate.

\section{RESULTATE}

\section{Individuele resultate}

Elke individuele persoon se persoonlikheidsprofiel is bepaal om te verseker dat daar wel 'n groot mate van ooreenstemming voorgekom het in die groep se resultate en dat daar nie individue is wat glad nie met die groep ooreenstem nie.

Tabel 2: Individuele eerste-orde en tweede-orde faktortellings van die 16PF-persoonlikheidsvraelys vir al die sprekers met nodules weens funksionele stemhiperfunksie

\begin{tabular}{|c|c|c|c|c|c|c|c|c|c|c|c|c|c|c|c|c|c|c|c|c|c|}
\hline \multirow[t]{2}{*}{$\begin{array}{l}\text { Proef- } \\
\text { persoon }\end{array}$} & \multicolumn{16}{|c|}{ Faktortellings van eerste-orde faktore } & \multicolumn{5}{|c|}{$\begin{array}{c}\text { Faktortellings van } \\
\text { tweede-orde faktore }\end{array}$} \\
\hline & A & $\mathrm{B}$ & $\mathrm{C}$ & $\mathrm{E}$ & $\mathrm{F}$ & G & $\mathrm{H}$ & I & $\mathrm{L}$ & M & $\mathrm{N}$ & 0 & Q1 & Q2 & Q3 & Q4 & QI & QII & QIII & QV & QVIII \\
\hline A & 4 & 5 & 7 & 5 & 7 & 5 & 8 & 5 & 4 & 5 & 5 & 7 & 1 & 4 & 4 & 5 & 6.2 & 5.4 & 6.3 & 3.3 & 4.5 \\
\hline B & 3 & 7 & 6 & 5 & 8 & 5 & 7 & 3 & 6 & 7 & 4 & 4 & 6 & 2 & 6 & 3 & 6.4 & 5 & 6.6 & 4.3 & 6 \\
\hline$C$ & 7 & 3 & 5 & 5 & 5 & 6 & 7 & 7 & 4 & 7 & 6 & 7 & 5 & 3 & 5 & 6 & 6.4 & 6.2 & 4 & 4.3 & 5.5 \\
\hline $\mathrm{D}$ & 8 & 6 & 5 & 8 & 9 & 6 & 10 & 2 & 7 & 3 & 4 & 4 & 1 & 4 & 2 & 6 & 8.4 & 6.8 & 6.6 & 4.3 & 5.5 \\
\hline$E$ & 8 & 4 & 6 & 8 & 8 & 6 & 10 & 4 & 6 & 7 & 5 & 5 & 5 & 2 & 4 & 7 & 8.6 & 6.4 & 4.7 & 5 & 7 \\
\hline $\mathrm{F}$ & 6 & 1 & 3 & 6 & 5 & 6 & 5 & 8 & 9 & 9 & 7 & 6 & 4 & 4 & 3 & 10 & 5.8 & 8.2 & 3.3 & 4.7 & 4 \\
\hline G & 8 & 4 & 8 & 10 & 10 & 5 & 10 & 6 & 6 & 7 & 3 & 4 & 4 & 2 & 3 & 8 & 9.4 & 6.2 & 4 & 5.3 & 4.5 \\
\hline $\mathrm{H}$ & 10 & 3 & 9 & 8 & 10 & 6 & 10 & 2 & 6 & 3 & 5 & 4 & 4 & 1 & 8 & 3 & 9.6 & 4 & 6 & 4.3 & 5 \\
\hline I & 8 & 5 & 4 & 10 & 9 & 6 & 9 & 3 & 6 & 8 & 4 & 6 & 4 & 4 & 5 & ' & 8.6 & 6.8 & 4.7 & 6 & 4 \\
\hline $\mathrm{J}$ & 6 & 3 & 4 & 6 & 7 & 6 & 7 & 6 & 4 & 5 & 4 & 4 & 4 & 5 & 6 & 6 & 6.4 & 5.4 & 5.3 & 5 & 5.5 \\
\hline $\mathrm{K}$ & 3 & 6 & 10 & 8 & 9 & 6 & 9 & 4 & 6 & 5 & 5 & 1 & 6 & 5 & 5 & 3 & 7 & 3.6 & 7 & 6.3 & 5.5 \\
\hline $\mathrm{L}$ & 8 & 7 & 6 & 9 & 9 & 5 & 10 & 7 & 7 & 7 & 5 & 6 & 7 & 4 & 4 & 7 & 8.6 & 7 & 3.7 & 6.7 & 4.5 \\
\hline Totaal & 79 & 54 & 73 & 88 & 89 & 68 & 102 & 57 & 71 & 63 & 57 & 58 & 51 & 40 & 55 & 71 & 91.4 & 70.6 & 62.2 & 59.5 & 61.5 \\
\hline Stien & 6.6 & 4.5 & 6 & 7.3 & 8 & 5.7 & 8.5 & 4.8 & 6 & 6 & 4.8 & 4.8 & \begin{tabular}{|l|}
4.3 \\
\end{tabular} & 3.3 & 4.6 & 6 & 7.6 & 5.9 & 5.2 & 5 & 5.12 \\
\hline
\end{tabular}


Tabel 2 verskaf die individuele proefpersone se faktortellings volgens die verskillende faktorskale. Die groep het 'n groot mate van ooreenkoms getoon in die verspreiding van hul resultate, maar daar was ook sommige individuele resultate wat verskil het van die groep se resultate. Proefpersoon $\mathrm{H}$ se faktortellings het grootliks ooreengestem met die res van die groep (Tabel 2), maar haar faktortellings was gewoonlik meer ekstreem. Soos reeds genoem, het sy 'n hoë MD-telling wat moontlik haar ekstreme faktortellings kan verklaar. Proefpersoon $\mathrm{F}$ se resultate het soms grootliks verskil van die res van die groep se faktortellings, veral ten opsigte van die faktorskale waar die res van die groep 'n groot mate van ooreenstemming getoon het (verwys na faktorskale $\mathrm{F}, \mathrm{H}$ en tweede-orde faktorskaal QIl op tabel 2). Proefpersoon F studeer musiek en word opgelei in die professionele gebruik van haar sangstem. Haar stemhiperfunksie word moontlik meer geassosieer met haar sangstem, as met haar spraakstem wat sy vir interpersoonlike kommunikasie gebruik. Dit sou dus verklaar waarom haar faktortellings verskil van die groep se resultate en verder bevestig hierdie uitsondering in 'n sin die resultate van die groep.

\section{Algemene persoonlikheidsprofiel van die proefgroep}

'n Algemene persoonlikheidsprofiel van die proefgroep word visueel voorgestel in Figuur 1. Die twee-en-twintig skale dui op die kontinuum van elke persoonlikheidsfaktor en karakterbeskrywings van die twee uiterste pole van elke skaal word gegee. Faktortellings van 4 tot 7 toon die gemiddelde gebied van die faktorskaal aan. Dit beteken dat 'n telling in hierdie gebied reeds geïnterpreteer kan word as 'n neiging na een van die twee pole van die faktorskaal, maar dat dit steeds binne normale perke voorkom, in vergelyking met die populasie waarteen die toetsgroep gemeet word (In hierdie geval eerstejaar damestudente). Wanneer 'n telling op 'n faktorskaal voorkom tussen 1 en 3 of tussen 8 en 10, beteken dit dat die spesifieke karaktereienskap sterker teenwoordig is by die toetsgroep as in die normpopulasie.

\begin{tabular}{|c|c|c|c|c|c|c|c|c|c|c|c|c|c|}
\hline & Faktorpool & \multicolumn{10}{|c|}{ Kontinuum van faktorskaal } & \multicolumn{2}{|l|}{ Faktorpool } \\
\hline & Lae telling beskrywing & 1 & 2 & 3 & 4 & 5 & 6 & 7 & 8 & 9 & 10 & Hoë telling beskrywing & \\
\hline & \multicolumn{13}{|c|}{ Eerste-orde faktore } \\
\hline A & Terughoudend & & & & & & & & $\mathbf{X}$ & & & Hartlik & $A$ \\
\hline$B$ & Laer intelligensie & & & & & $\mathbf{x}$ & & & & & & Hoër intelligensie & $B$ \\
\hline $\mathrm{C}$ & Beinvloedbaar & & & & & & $\mathbf{X}$ & & & & & Emosioneel stabiel & C \\
\hline$E$ & Nederig & & & & & & & $\mathbf{X}$ & & & & Selfgeldend & $E$ \\
\hline$F$ & Sober & & & & & & & & $\mathbf{X}$ & & & Onverskillig & $\mathbf{F}$ \\
\hline$G$ & Opportunisties & & & & & & $\mathbf{X}$ & & & & & Konsensieus & G \\
\hline $\mathrm{H}$ & Skaam & & & & & & & & & $\mathbf{X}$ & & Waaghalsig & $\mathbf{H}$ \\
\hline I & Ontoegeeflik & & & & & $\mathbf{X}$ & & & & & & Emosioneel gevoelig & I \\
\hline $\mathrm{L}$ & Vertrouend & & & & & & $\mathbf{X}$ & & & & & Agterdogtig & L \\
\hline$M$ & Prakties & & & & & & $\mathbf{X}$ & & & & & Verbeeldingryk & $\mathrm{M}$ \\
\hline $\mathrm{N}$ & Reguit & & & & & $\mathbf{X}$ & & & & & & Skerpsinnig & $\mathrm{N}$ \\
\hline $\mathrm{O}$ & Selfversekerd & & & & & $\mathbf{X}$ & & & & & & Bekommerd & $\mathrm{O}$ \\
\hline Q1 & Konserwatief & & & & $\mathbf{X}$ & & & & & & & Ondersoekend & Q1 \\
\hline Q2 & Groepsafhanklik & & & $\mathbf{X}$ & & & & & & & & Selfgenoegsaam & Q2 \\
\hline Q3 & Sorgeloos & & & & & $\mathbf{X}$ & & & & & & Selfbeheersd & Q3 \\
\hline Q4 & Ontspanne & & & & & & $\mathbf{x}$ & & & & & Gespanne & Q4 \\
\hline \multicolumn{14}{|c|}{ Tweede-orde faktore } \\
\hline QI & Introversie & & & & & & & & $\mathbf{X}$ & & & Ekstroversie & QI \\
\hline QII & Lae angs & & & & & & $\mathbf{x}$ & & & & & Hoë angs & QII \\
\hline QIII & Gevoelsafhanklikheid & & & & & $\mathbf{x}$ & & & & & & Kortikaliteit & QIII \\
\hline QIV & Afhanklik & & & & & $x$ & & & & & & Onafhanklik & QIV \\
\hline QV & Impulsief & & & & & $\mathbf{x}$ & & & & & & Kompulsief & QV \\
\hline
\end{tabular}

Figuur 1: Algemene persoonlikheidsprofiel op die 16PF persoonlikheidsvraelys van die groep sprekers met nodules weens funksionele stemhiperfunksie 
'n Uitstaande kenmerk van die groep wat duidelik na vore kom, is 'n sterk neiging tot ekstroversie. Dit kan afgelei word van 'n hoë telling op die tweede-orde faktorskaal $Q I$, asook vanaf hierdie tweede-orde faktor se samestellende eerste-orde faktore, nl. 'n hoë telling van 7.6 op faktorskaal A (wat dui op hartlikheid), 'n hoë telling op faktorskaal $F$ (wat dui op onverskilligheid), 'n hoë telling op faktorskaal $\mathrm{H}$ (wat dui op waaghalsigheid) en 'n lae telling op faktorskaal Q2 (wat dui op groepsafhanklikheid). Buiten die groep se hartlike karaktereienskap (faktor $A$ ), is daar nog twee ander eienskappe van die groep waar hulle faktortellings op die grens van die gemiddelde gebied voorkom, nl. 'n neiging om konserwatief (faktor Q1) en selfgeldend (faktor E) te wees.

Die res van die groep se persoonlikheidseienskappe se faktortellings kom in die gemiddelde gebied (dus tellings tussen 4 en 7) voor en verskil dus in hierdie opsig nie grootliks van hulle portuurgroep nie. Hierdie eienskappe dui op 'n neiging om meer konkrete denke te vertoon as abstrakte denke (faktor B) en om stabiele houdings en gesindhede te toon (faktor $\mathrm{C}$ ). Die groep neig ook om vasberade en verantwoordelik te wees (faktor G), selfstandig te wees en logies te redeneer (faktor I). Hulle kan ook soms 'n sterk opinie hê oor 'n saak en ander wantrou (faktor $L$ ) en hulle hou van struktuur en objektiewe werklikheid (faktor M). Die groep neig om opreg en ongekunsteld te wees (faktor N) en toon vertroue in hulle eie oordeel (faktor $\mathrm{O}$ ). Hulle heg nie soveel waarde aan sosiale etiket nie (faktor Q3), is aktief en toon dryfkrag (faktor Q4).

\section{BESPREKING VAN DIE RESULTATE}

\section{Uitstaande kenmerke van die groep}

In hierdie studie is 'n persoonlikheidsprofiel saamgestel vir'n groep sprekers met funksionele stemhiperfunksie en gevolglike nodules. Alhoewel daar individuele verskille voorgekom het, het die groep se uitstaande kenmerke getuig van sekere tendense in die hele groep. Die groep se mees kenmerkende karakterbeskrywing is hul ekstroversiewe geaardhede (2de-orde faktorskaal QI, Figuur 1). Yano, et al. (1982) het ook verhoogde vlakke van ekstroversie geïdentifiseer by 'n groep persone met nodules teenoor 'n groep persone met geen stemafwykings nie. Hulle gevolgtrekking was dat oormatige stemgebruik, wat 'n risiko is vir die ontstaan van nodules, 'n manifestasie is van 'n ekstroversiewe geaardheid. Soortgelyke resultate is verkry deur Roy et al. (2000a). Dit lyk dus of daar' $n$ algemene neiging kan voorkom by persone met nodules weens stemhiperfunksie om ekstroversief van geaardheid te wees.

Die onderskeie eerste-orde faktore wat gekombineer word om die vlak van ekstroversie (tweede-orde faktor I) te bereken (nl. faktor A, F, H en Q2), sal verder bespreek word ten einde verder ondersoek in te stel na die verband tussen ekstroversie en die risiko vir die ontstaan van stemhiperfunksie. Die eerste faktor wat gebruik word om die vlak van ekstroversie (tweedeorde faktor I) te bepaal, is faktor A. Die proefgroep blyk meer hartlik as terughoudend te wees (eerste-orde faktorskaal A, Figuur 1). McHugh-Munier, Schrerer, Lehmann en Schrerer (1997) het 'n studie gedoen waarin 'n simptomatologiese beeld van vroulike sprekers met nodules saamgestel is. Hulle het onder andere verhoogde vlakke van altruïsme geïdentifiseer by die proefgroep van 17 vroulike sprekers met nodules, teenoor ' $n$ kontrolegroep van 61 vroulike sprekers sonder stembandpatologie. Altruïsme dui op onselfsugtigheid en liefde vir die naaste (Schoonees, Swanepoel, du Toit \& Booysen, 1972:33), wat korreleer met Cattell (1989) se beskrywing van persone met verhoogde faktor A-tellings, $\mathrm{nl}$. as persone met innige, warm emosionele response teenoor hul naaste en 'n lewensleuse van 'hoe meer siele, hoe meer vreugde'. Hierdie persone word beskryf as die sogenaamde 'people's person' wat groepsprojekte verkies bo individuele kompetisie, asook beroepe wat interpersoonlike kontak noodsaak (Cattell, 1989:15).

Die tweede faktor wat gebruik word om die vlak van ekstroversie te bepaal, is faktor F. Die groep toon 'n sterk neiging na onverskilligheid eerder as soberheid (faktor F, Figuur 1). Vanuit die Engelse beskrywing vir faktorskaal F, nl. 'exuberant versus somber', sou 'n ander vertaling miskien 'uitgelate teenoor swaarmoedig' kon wees (Eksteen, 1997). Die groep sou dus ook beskryf kon word as uitgelate eerder as swaarmoedig. Volgens die groep se hoë telling op faktorskaal F neig hulle om aandagsoekend en selfgesentreerd te wees en sukkel somtyds om hul gedrag te kontroleer. Die groep se hoë telling op die faktorskaal word egter versag deur hul hartlikheid (faktorskaal A), wat hul belangstelling en warm response op ander verhoog, 
teenoor hul selfgesentreerdheid. Cattell (1989:97) beskryf hierdie persone as 'fast cars without brakes', wat soms nie hulle uitgelatenheid kan inhibeer nie. Hulle neig om baie entoesiasties te reageer op enigiets as dit by hulle byval vind. In 'n sosiale konteks sal hulle gemaklik wees tydens gesprekvoering en ook baie spraaksaam en vermaaklik wees met 'n skerp sin vir humor. Persone met hoë tellings in faktor $F$ kan selfs later die geduld van gespreksgenote beproef met hul konstante aandrang op aandag. Hierdie bevinding bevestig vroeë opvattings in die literatuur wat persone met nodules beskryf as spraaksaam (Arnold, 1962; Green \& Mathieson, 1989; Aronson, 1990). Die groep se hoë tellings in Faktor $F$ (as ' $n$ samestellende faktor vir 'n persoon se vlak van ekstroversie) kan dus 'n predisposisie veroorsaak om funksionele stemhiperfunksie en gevolglike nodules te ontwikkel. 'n Verklaring hiervoor kan wees dat dit 'n neiging tot spraaksaamheid meebring wat die persoon se hoeveelheid stemgebruik vermeerder en so die risiko verhoog vir die ontstaan van stemhiperfunksie (Yano et al. 1982).

Die derde faktor wat gebruik word om die vlak van ekstroversie te bepaal, is faktor $\mathrm{H}$. Volgens Faktorskaal $\mathrm{H}$ toon die groep ook 'n sterk neiging tot waaghalsigheid. Hierdie karaktereienskap word goed omskryf deur die Engelse beskrywing van Cattell (1989), nl. 'boldness', wat vertaal kan word as vrymoedigheid, dapperheid en waagmoed. Die groep het dus 'n sterk sin vir ondernemingsgees en sal in 'n sosiale konteks waarskynlik nie skroom om hulself aan vreemdes voor te stel of 'n gesprek te inisieer nie. Vanweë die groep se hoë telling op die faktorskaal, is die groep waarskynlik sosiaal aggressief (Cattell, 1989) en kan selfs sosiopatiese gedragskenmerke toon, deurdat hulle neig om immuun voor te kom teenoor die druk wat die samelewing toepas om individue te konformeer. Hierdie bevinding bevestig ook vroeë algemene opvattings in die literatuur, sowel as resente navorsing, wat persone met stembandnodules as sosiaal aggressief beskou (Moses, 1954; Arnold, 1962; Aronson, 1990; Roy \& Bless, 2000b). Aronson (in Roy, Bless \& Heisey, 2000b) beskou stemmisbruik en stemwangebruik (kenmerkend van stemhiperfunksie) as sekondêr tot 'n onderliggende aggressiewe eienskap wat 'n neiging meebring om 'aggressief' te vokaliseer. Die groep se sterk neiging tot waaghalsigheid (of vrymoedigheid) kan dus die risiko verhoog vir die ontstaan van funksionele stemhiperfunksie en gevolglike nodules, deurdat die persoon neig om 'aggressief' te vokaliseer en dus hul stemme te misbruik of wangebruik.

Die laaste faktor wat gebruik word om die vlak van ekstroversie te bepaal, is faktor Q2. Volgens faktorskaal Q2 neig die groep om baie groepsafhanklik te wees. Hulle ervaar waarskynlik ' $n$ innerlike behoefte om 'te behoort', of om 'in te pas'. Groepsafhanklike persone verkies die geselskap van ander bo isolasie en kan selfs ongemaklik of angstig voel indien hulle nie kan identifiseer in groepsverband nie. Cattell (1989) beskryf dit as ' $n$ tipe skeidingsangs wat die persoon kan ervaar indien hy of sy nie die sekuriteit van 'n groep ervaar nie.

Ter samevatting blyk dit dus, vanuit die samestellende faktore van ekstroversie, dat die groep se sterk neiging tot ekstroversie verband kan hou met stemhiperfunksie en die ontstaan van nodules (Maree, 2001). Die groep ervaar probleme om hulle uitgelatenheid te kontroleer of gematig te hou (faktor F) en is besonder spraaksaam, wat die risiko verhoog vir die ontstaan van stemhiperfunksie. Verder toon hulle 'n neiging om 'aggressief' en met vrymoedigheid te vokaliseer (faktor $\mathrm{H}$ ), wat kan lei tot stemmisbruik. Tesame met die groep se uitgelate en sosiaal-aggressiewe gedrag in 'n sosiale konteks, spandeer hulle baie tyd in die geselskap van ander, vanweë hulle afhanklikheid van 'n groep (faktor Q2) en hulle liefde vir ander mense (faktor A), wat hulle hoeveelheid stemgebruik selfs nog verder vermeerder. Al die bogenoemde faktore (wat verbandhoudend is met die groep se ekstroversiewe geaardhede), veroorsaak dus gedragspatrone wat die risiko verhoog vir die ontstaan van stemhiperfunksie.

\section{Bevindings wat huidige opvattings in die literatuur bevraagteken}

Die onvermoë van die proefgroep om hul uitgelatenheid te kontroleer of te inhibeer in 'n geselskap (hoë telling op eerste-orde faktorskaal $F$ ), lok verdere bespreking uit. Roy en Bless (2000b) het onlangs 'n soortgelyke beskrywing gegee van persone wat presenteer met nodules. Hulle noem dat, ten spyte van ooglopende skadelike gevolge (soos ongemak en stemveranderinge) van aanhoudende stemmisbruik en oormatige stemgebruik, persone met nodules nie hul 
stemgebruik toepaslik kan kontroleer en gematig hou in die teenwoordigheid van verwagte sosiale beloning vir hul gedrag nie (Roy \& Bless, 2000b). Roy en Bless (2000b) se verklaring vir bogenoemde beskrywing is egter aanvegbaar. Hulle stel voor dat persone wat presenteer met nodules 'n onvermoë het om hulle stemgebruik te kontroleer op grond van verhoogde vlakke van ekstroversie, impulsiwiteit en neurose. Die resultate van die huidige studie is egter teenstrydig hiermee. Alhoewel die proefgroep verhoogde vlakke van ekstroversie toon, verskil die groep se neiging tot impulsiwiteit (tweede-orde faktorskaal V, Figuur 1) nie grootliks van die norm nie. Hulle toon ook nie 'n neiging om neuroties te wees nie. Cattell (1970) noem dat 'n neurotiese persoonlikheidsprofiel gekenmerk word deur lae egosterkte (verlaagde vlakke van faktor C), 'n tekort aan 'n vermoë om 'n probleem met selfvertroue en eie inisiatief op te los (verlaagde vlakke van faktor $E$ ) en 'n groot mate van inhibisie (verlaagde vlakke van faktor $F)$, met verlaagde ekspressie van die superego (verlaagde vlakke van faktor $\mathrm{G}$ ). 'n Neurotiese persoon sal ook gewoonlik nie ondernemingsgees toon nie (verlaagde vlakke van faktor $\mathrm{H}$ ), is oorgevoelig (verhoogde vlakke van faktor I), vertoon hoë vlakke van angstigheid (verhoogde vlakke van faktor Q4) en 'n gevoel van skuld en onwaardigheid (verhoogde vlakke van faktor O). Die proefgroep se profiel spreek egter nie van geneigdheid tot neurose nie. Cattell (1970) het 'n formule bereken om neurose as 'n stiengetal te kwantifiseer. Die stien word bereken deur die persoon se faktortellings op die 16PF-persoonlikheidsprofiel en is ooreenstemmend met die skale wat deur Roy en Bless (2000b) gebruik is om neurose te meet. Die proefgroep se stien op die skaal is 4.36 , wat aantoon dat die groep nie 'n neiging toon om neuroties te wees nie. Dit wil dus voorkom of die resultate van die huidige studie bevestigend is van Roy en Bless (2000b) se bevinding dat persone wat presenteer met nodules geneig is om nie hul hoeveelheid en wyse van stemgebruik te kan kontroleer of beperk nie, maar dit kan bevraagteken word of hierdie persoonlikheidseienskap meegebring word deur verhoogde vlakke van neurose en impulsiwiteit.

'n Verdere bevinding in die huidige studie wat teenstrydig is met bestaande navorsingsbevindings, is gegrond op die groep se angs- en spanningsvlakke. Alhoewel die proefgroep meer gespanne as ontspanne is (faktor Q4) en neig om verhoogde angsvlakke te hê (tweede-orde faktor QII), val hierdie waardes nog binne normale perke en is nie aanduidend van abnormale of ontwrigtende spanning of angs nie. Algemene opvattings en navorsingsbevindings in die literatuur is egter teenstrydig hiermee. Roy, McGrory en Bless (1995), asook Goldman et al. (1996) het in soortgelyke studies verhoogde vlakke van angs geïdentifiseer in vroue met nodules, in vergelyking met vroue sonder stembandpatologie. White, Dreary en Wilson (1997) het ook 'n verskil opgemerk in angsvlakke tussen persone met stemafwykings (insluitend funksionele en organiese stemafwykings) en oor-, neus- en keelpasiënte sonder stembandpatologie. Aronson (1990) reken ook dat onderliggende emosionele spanning die hoofrede is vir die ontstaan van nodules. In die lig hiervan, sou daar dus verwag word dat die proefgroep sterker tellings op faktorskale Q4 en QII sou toon. Daar is wel aanduidings dat die groep onderliggende emosionele spanning kan ervaar, wanneer die verhoudings tussen die groep se onderskeie faktore ondersoek word (Maree, 2001). Die groep toon 'n neiging om konserwatief te wees en alhoewel die groep se telling op hierdie faktorskaal (faktor Q1) nog op die grens van die gemiddelde gebied van die faktorskaal voorkom, noem Cattell (1989) dat persone wat tellings van 4 of 5 het, reeds baie konserwatief kan wees en verandering kan teenstaan. Sulke persone neig om tradisionele weë te volg en om nuwe idees en voorstelle te vermy. Die voorkoms van 'n konserwatiewe eienskap, in teenstelling met 'n sterk neiging tot waaghalsigheid (faktor $\mathrm{H}$ ) en onverskilligheid (faktor F), toon 'n dualistiese persoonlikheidsbeeld (Maree, 2001) wat moontlik onderliggende emosionele spanning kan meebring. 'n Moontlike verklaring vir die feit dat hierdie spanning nie weerspieël word in die groep se profiel nie, is dat die groep hanteringsmeganismes aangeleer het om hul angs te onderdruk of om dit te verlig (Maree, 2001).

\section{Funksionele stemhiperfunksie as 'n psigogene stemafwyking}

Daar kan verskillende vorme van psigologiese disekwilibrium voorkom wat kan manifesteer as 'n stemafwyking en die aard van die oorsaaklike psigologiese faktore of disekwilibrium kan 'n invloed hê en waarskynlik bepalend wees ten opsigte van die aard van die stemafwyking wat manifesteer. Psigogene stemafwykings sluit onder andere die volgende in: 'n 
konversie afwyking waar daar skielike verlies van die stem is, mutasie falset waar die volwasse man sy kinderstem bly gebruik en kindertipe spraak en stem by vrouens. Die psigodinamiek onderliggend aan elk van hierdie tipes afwyklings is waarskynlik verskillend. Daar is aanduidings dat die groep in hierdie studie se stemhiperfunksie 'n konversie reaksie is, deurdat die groep se ekstroversiewe geaardhede omgeskakel of oorgedra word na spraakgedrag wat lei tot stemhiperfunksie soos harde glottale aanset en spanning van die farinkswande. Dit is verder baie interessant dat Cattell (1989) noem dat hoë tellings in faktor F, nl. onverskilligheid, wat een van die samestellende faktore vir die vlak van ekstroversie is, gereeld voorkom in persone met histeriese afwykings, veral waar konversiesimptome aanwesig is. Die proefgroep in die huidige studie het hoë vlakke van onverskilligheid vertoon en op grond daarvan kan die groep se stemhiperfunksie moontlik gesien word as 'n konversie reaksie op hulle algehele onvermoë om hulle uitgelatenheid te kontroleer of inhibeer.

Die afleiding dat die groep se stemhiperfunksie moontlik 'n manifestasie kan wees van hulle ekstroversiewe persoonlikhede, kan moontlik verklaar waarom spraaktaalterapeute vind dat persone wat presenteer met nodules nie altyd advies volg nie en dat nodules herhalend voorkom (Roy \& Bless, 2000a). Die rede hiervoor mag wees dat die persoon 'n diepgesetelde neiging het om spraakgedrag te toon wat lei tot stemhiperfunksie en gedragsregulerende terapie alleen is dus nie noodwendig ' $n$ effektiewe vorm van behandeling nie.

\section{GEVOLGTREKKINGS}

Die resultate van hierdie studie dui daarop dat meer aandag gegee moet word aan die psigologiese eienskappe van 'n persoon wat presenteer met stemband nodules. Gedragsterapie deur die spraaktaalterapeut alleen is waarskynlik nie effektief om stemhiperfunksie te behandel nie. Huidige evaluasieen behandelingsprotokolle sal heroorweeg en selfs aangepas moet word om 'n meer holistiese beskouing aan te hang van die persoon as geheel deur onder andere rekening te hou met bydraende persoonlikheidsfaktore. Die aanbeveling wat dus gemaak kan word, is dat 'n kliniese sielkundige betrek word by die behandeling van stemhiperfunksie. Dit is egter so dat slegs 'n klein groepie persone by hierdie studie betrek is en slegs 'n enkele persoonlikheidstoets toegepas is. Navorsing met groter groepe en meer diverse groepe en die gebruik van ook ander persoonlikheidsanalises sal die resultate van hierdie studie aanvul.

\section{VERWYSINGS}

ARNOLD, GE 1962: Vocal nodules and polyps: Laryngeal tissue reaction to habitual hyperkinetic dysphonia. Journal of Speech and Hearing Development, 27(3):205-217.

ARONSON, AE 1990: Clinical Voice Disorders; third edition. New York: Thieme-Stratton.

BOONE, DR 1991: Expanding perspectives in care of the speaking voice. Journal of Voice, 5(2):168-172.

BOONE, DR \& McFARLANE, SC 1993: The Voice and Voice Therapy; fifth edition. Englewood Cliffs, NJ: Prentice-Hall.

CATTELL, RB 1970: Handbook for the sixteen personality factor questionnaire (16PF). Illinois: Institute for personality and ability testing.

CATTELL, BC 1989: The 16PF: Personality in depth. Illinois: Institute for personality and ability testing.

DAWS, L 1999: A psychodynamic study of differentiation impairment and symbiotic need in burning mouth syndrome patients. Pretoria: Universiteit van Pretoria (Ongepubliseerde M.A. verhandeling in Kliniese Sielkunde).

DAWS, L 2001: Mondelinge mededeling, Universiteit van Pretoria. EKSTEEN, LC 1997: Groot Woordeboek (Afrikaans-Engels EngelsAfrikaans). Wes-Kaap: Nasionale Boekdrukkery.

GOLDMAN, SL; HARGRAVE, J; HILLMAN, RE; HOLMBERG, E \& GRESS, C 1996: Stress, anxiety, somatic complaints and vocal use in women with vocal nodules: Preliminary findings. American Journal of Speech-Language Pathology, 5:44-53.

GREENE, MCL \& MATHIESON, L 1989: The Voice and its Disorders; fifth edition. London: Whurr Publishers.

LAVORATO, AS \& McFARLANE, SC 1988: Counselling clients with voice disorders. Seminars in Speech and Language, 9(3):237253.

MAREE, JG 2001: Mondelinge mededeling. Fakulteit Opvoedkunde, Universiteit van Pretoria.

McHUGH-MUNIER, C; SCHRERER, KR; LEHMANN, W, \& SCHRERER, U 1997: Coping strategies, personality, and voice quality in patients with vocal fold nodules and polyps. Journal of Voice, 11(4):452-461.

MORRISON, M \& RAMMAGE, L 1994: The Management of Voice Disorders. San Diego: Singular Publishing Group.

MOSES, PJ 1954: The Voice of Neurosis; first edition. New York: 
NEUMAN, WL 1997: Social Research Methods: Qualitative and Quantitative Approaches; third edition. Boston: Allyn \& Bacon.

PRINSLOO, CH 1991: The norms, means, standard deviations and reliability coefficients for the 16-Personality Factor Questionaire (form A). Pretoria: Human Science Research Centre.

ROY, N; McGRORY, JJ \& BLESS, DM 1995: Psychological correlates of patients with vocal fold nodules. ASHA Conference. New Orleans, L.A.

ROY, N \& BLESS, DM 2000a: Personality traits and psychological factors in voice pathology: a foundation for future research. Journal of Speech, Language, and Hearing Research, 43:737-748. ROY, N \& BLESS, DM 2000b: Toward a theory of the dispositional bases of functional dysphonia and vocal nodules: Exploring the role of personality and emotional adjustment. (In: Kent, RD \& BALL, MJ eds. 2000: Voice quality measurement. Canada: Transcontinental Printing, pp. 461-480).

ROY, N; BLESS, DM \& HEISEY, D 2000a: Personality and voice disorders: a superfactor trait analysis. Journal of Speech, Language, and Hearing Research, 43:749-768.

ROY, N; BLESS, DM \& HEISEY, D 2000b: Personality and voice disorders: A multitrait-multidisorder analysis. Journal of Voice, 14:521-548.

RUBIN, HJ \& LEHRHOFF, I 1962: Pathogenesis and treatment of vocal nodules. The Journal of Speech and Hearing Disorders, 27(2):150-161.

SCHOONEES, PC; SWANEPOEL, CJ; DU TOIT, SJ \& BOOYSEN, CM 1972: Handwoordeboek vir die Afrikaanse Taal; eerste uitgawe; vierde druk. Pretoria: Voortrekker Pers.

SMIT, GJ 1991: Psigometrika: Aspekte van Toetsgebruik. PretoriaWes: Gutenberg Boekdrukkers.

WHITE, A; DREARY, IJ \& WILSON, JA 1997: Psychiatric disturbance and personality traits in dysphonic patients. European Journal of Disorders in Communication, 32:307-314.

YANO, J; ICHIMURA, K; HOSHINO, T \& NOZUE, M 1982: Personality factors in pathogenesis of polyps and nodules of vocal cords. Auris Nasus Larynx (Tokyo), 9:105-110. 